DOI: https://doi.org/10.15407/techned2019.01.007

\title{
STOCHASTIC IDENTIFICATION MODEL FOR FORECASTING OF PARAMETERS OF DEVICES OF ELECTRIC TRANSPORT SYSTEMS
}

Journal

Publisher

ISSN

Issue

Pages
Tekhnichna elektrodynamika

Institute of Electrodynamics National Academy of Science of Ukraine 1607-7970 (print), 2218-1903 (online)

No 1, 2019 (January/February)

$7-15$

\section{Authors}

\section{Kostin*, T. Mishchenko**}

Dnipropetrovsk National University of Railway Transport named after Academician V.

Lazaryan,

Lazaryan Str., 2, Dnipro, 49010, Ukraine,

e-mail: nkostin@ukr.net, mishchenko_tn@ukr.net

* ORCID ID : http://orcid.org/0000-0002-0856-6397

** ORCID ID : http://orcid.org/0000-0001-6336-7350

\begin{abstract}
The necessity to create mathematical models of complex powerful devices of electric traction systems which provide speed and high-speed train movements using identification methods has been justified. A pulse transition function is recommended to be used as an identification model. Using correlation theory for stochastic processes which are voltage and currents in electric traction systems, analytic expression of correlation Wiener-Hopf integral equation has been obtained. Solution of the equation makes it possible to obtain a pulse transition function.
\end{abstract}


Operational, numerical and factorization methods for the equation solving have been considered. Auto- and intercorrelation functions of stochastic current and voltage processes in the system, which are necessary for the solution of integral equation, were defined using experimental method on functioning sections of railroad. Using numerical and factorization methods a pulse transition function as a forecast model was defined for electric locomotive of a direct current DE1 used on electrified sections of Prydneprovska railway. For this purpose monitoring of stochastic voltage and traction current processes was conducted in real operating conditions. Pulse transition functions were defined as exponential functions. References 24, figures 4 . table 1.

Key words: identification, model, forecasting, weight function, stochastic process, electric traction.

Received: 19.12 .2017

Accepted: 26.06 .2018

Published: 10.01 .2019

\section{References}

1. Biesenack N. Traction power supply of high-speed lines. Zheleznye dorogi mira. 2001. No 6. P. 26-30. (Rus)

2. Markvardt K G. Electrosupply of electrified railways. Moskva: Transport. 1982. 528 p. (Rus)

3. Bosyi D.O. Method of calculation of instantaneous traction power supply schemes for constant power consumption. Elektryfikatsiia transportu. No 8. 2014. Pp .15-24. (Ukr)

4. Gigch J.M, Alphen G. Ac traction power supply design and EMC verification. 6th Intern. Conf. Modern Electric Traction in Integrated XXIst Century Europe ( MET'2003). Warsaw. September 25-27. 2003. Pp. 1-6.

5. Jefimowski W., Nikitenko A. Case study of stationary energy storage device in a 3 kV DC 
traction system. 13 ${ }^{\text {th }}$ In-ternational Conference Modern Electric Transport (MET'2017). Warsaw. October 5-7. 2017. Pp. 26.

6. Kostin M. O., Sheikina O. H. Theoretical foundations of electrical engineering. Tom II. Dnipropetrovsk: Vyd-vo DNUZT. 2007. 276 p. (Ukr)

7. Mishchenko T.N., Mikhalichenko P.Ye., Kostin N.A. Probabilistic characteristics of the random voltage function on the current collector of the first Ukrainian electric locomotive DE 1. Elektrotekhnika i elektromekhanika

. 2003. No 2. Pp. 43-46. (Rus)

8. Kostin N., Mishenko T., Reutskova O. Stochastic Electromagnetic Processes in Power Circuits of Electric Locomotive at a Sharp Change of Voltage on a Current Collector. 7th Intern. Conf. Modern Electric Traction in Integrted XXIst Century Eurupe. Warsaw. 29.09-01.10. Pp. 227-232.

9. Kostin M. Statistics and Probability of the Pantograph of DC Electric Locomotive the Recuperation Mode. Przeglad Elektrotechniczny. 2013. No 2a. Pp. 273-275.

10. Khvorost N.V. Electric railways: stages and prospects of development. Elektrotekhnika $i$ elektromekhanika.

2003. No 4. Pp. 104-114. (Rus)

11. Khvorost N.V. Goncharov Yu.P., Panasenko N.V. Improvement of electric traction of direct current in Ukrainian railways for high-speed passenger traffic. Zaliznichniy transport Ukraïni. 2003. No 6. Pp. 11-18. (Rus)

12. Mishchenko T.M. Prospects for circuit design and simulation of subsystems of electric traction at high speed trains. Elektrotekhnika i Elektroenerhetyka. 2014. No 1. Pp. 19-28. (Ukr) 13. Mitrofanov A.M., Taranin M. A. Structure and mathematical identification model of traction power supply system. Elektrifikatsiya i nauchno-tekhnicheskiy progress na zheleznodorozhnom transporte . (Eltrans'2003). Sankt-Peterburg. 2003. Pp. 348-349. (Rus)

14. Grop D. Methods of system identification: monograph. Moskva: Mir, 1979. 302 p. (Rus) 15. Modern methods of identifying systems. Moskva: Mir, 1983. 400 p. (Rus)

16. Pavlenko S.V. Methods and tools for identification of nonlinear dynamical systems based on Volterra models. Avtoreferat dysert. k.t.n. za spets. 01.05 .02 - matematychne modeliuvannia ta obchysliuvalni metody. Odeskyi nats. politekhnichnyi universytet. Odesa, 2016. 24 p. (Ukr) 17. Shefer O.V. Modern method of identification of nonlinear signals of radio engineering systems. Systemy ozbroiennia i viiskova tekhnika. 2017. Vyp.1 (49). Pp.185-189. (Ukr) 18. Minucci S., Pagono M., Proto D. Model of the $2 \times 25 \mathrm{kV}$ high speed railway supply system taking into account the soilair interface. International Journal of Electrical Power and Energy System

/10.1016/j.ijepes.2017.09.017

19. Livshits N. A., Pugachev V. N. Probabilistic analysis of automatic control systems. Moskva: Sovetskoe radio. 1963. 896 p. (Rus)

20. Solodovnikov V.V. Statistical dynamics of automatic control systems. Moskva: Fizmatgiz. 1960. 655 p. (Rus)

21. Kostin N.A., Sheykina O.G. Noncanonical spectral decomposition of random functions of traction voltage and current in electric transport systems. Elektrotekhnika i elektromekhanika. 2015. No 1. Pp. 68-71. (Rus)

22. Kostin N.A., Sablin O.I. Methods of correlation-spectral analysis of voltage on current collector and traction current of electric transport. Konf. Problemy i perspektivy razvitiya zheleznodorozhnogo transporta 
Dnepropetrovsk. 2009. Pp. 130-131.

23. Kostin N., Mishchenko T., Shumikhina L. Correlation theory of casual processes in electrical power problems for systems of electric transport. Proceedings of the $16^{\text {th }}$ International Workshop Conference Computational Problems of Electrical Engineering (CPEE), 2015. September 2-5, 2015 (Kostryna, Trans-Carpathian region, Ukraine) IEEE. Lviv. 2015. P. 84-87.

24. Kotelnikov A. Basic requirements for systems and devices for traction power supply of high-speed and high-speed highways. 6th International Conference Modern Electric Traction in Integrated XXIst Century Europe

(MET'2003). Warsaw. September 25-27. 2003. Pp. 35-41. (Rus)

\section{PDF}

